\title{
Hepatitis B virus infection in patients with rheumatic diseases
}

\author{
HENRIK PERMIN, JAN ALDERSHVILE, AND JENS O. NIELSEN \\ From the Department of Internal Medicine, Divisions of Hepatology and Rheumatology, Hvidovre Hospital, \\ University of Copenhagen, Denmark
}

SUMmary Two hundred and thirty-nine patients with different rheumatic diseases were investigated for serological markers of hepatitis B virus (HBV) infection. An increased prevalence of anti-HBs was found in patients with systemic lupus erythematosus. The total prevalence of $\mathrm{HBV}$ markers in patients with polymyalgia rheumatica, temporal arteritis, juvenile and adult rheumatoid arthritis (RA), and systemic sclerosis was not significantly different from age-matched controls. Remarkably, 6 patients were HBsAg-positive of whom 3 had RA (4\%). Two patients with RA were 'healthy' $\mathrm{HBsAg}$ carriers. The third patient had circulating $\mathrm{HBeAg}$ as well and had shown progression from acute hepatitis to cirrhosis during the time of observation. Three of 18 patients with polyarteritis nodosa were $\mathrm{HBsAg}$ - and $\mathrm{HBeAg}$-positive, and all 3 were young men. Clinical improvement was seen in one of these patients and was associated with seroconversion from $\mathrm{HBeAg}$ to anti-HBe. Our data do not support the theory that $\mathrm{HBV}$ is an aetiological factor in rheumatic diseases except in some cases of polyarteritis nodosa.

The hepatitis B virus (HBV) infection has been reported to be associated with liver diseases as well as various types of extrahepatic manifestations. Immune complex manifestations of the HBV that have been reported include prodromal serum sickness in acute hepatitis, membranous glomerulonephritis, cutaneous vasculitis, infantile papular acrodermatitis, essential mixed cryoglobulinaemia, and polyarteritis nodosa (PAN). ${ }^{1}$ Furthermore, an association of $\mathrm{HBV}$ infection with other inflammatory syndromes has been suggested in diseases such as rheumatoid arthritis, ${ }^{2}$ polymyalgia rheumatica, ${ }^{3}$ and polymyositis. ${ }^{4}$

In the present study a group of patients with various rheumatic diseases were investigated for the presence of hepatitis B surface antigen (HBsAg), antibody to $\mathrm{HBsAg}$ (anti-HBs), hepatitis $\mathrm{B}$ e antigen ( $\mathrm{HBeAg}$ ), and antibody to $\mathrm{HBeAg}$ (anti-HBe) in order to clarify the association between HBV and rheumatic diseases.

\section{Patients and methods}

Included in the study were all patients seen by one of the authors (H.P.) in either the ward or the

Accepted for publication 18 August 1981.

Correspondence to Dr H. Permin, M 7505, Rigshospitalet, Copenhagen, Denmark. outpatients clinic during a 2-year period. Only patients fulfilling the diagnostic criteria mentioned below were included in the study.

Juvenile rheumatoid arthritis (JRA). Of the 34 patients 25 were girls, mean age 10 years (range 1.5-20 years) at the time of investigation. The diagnosis was based on internationally accepted criteria. ${ }^{5}$

Rheumatoid arthritis $(R A)$. Sixty-two women and 12 men with classical or definite $\mathrm{RA}^{6}$ were included. The mean age was 60 years (17-79 years).

Temporal arteritis $(T A)$. Included were 23 women and 4 men with typical giant cell arteritis diagnosed on biopsy specimens from one or both temporal arteries. The mean age was 75 years (range 55-85 years).

Polymyalgia rheumatica (PMR). Of 27 patients 21 were females and the mean age was 71 years (range 58-88 years). The diagnosis was based on pain and stiffness in the region of the neck or shoulder, the lumbar region, the buttocks, and the thighs accompanied by systemic symptoms such as fever, malaise, and loss of weight. The results of temporal artery biopsy were normal in all patients.

Systemic lupus erythematosus (SLE). In this group of 32 patients 28 were women. The mean age was 48 years (range 15-79 years), and diagnostic criteria were those of the American Rheumatism Association. ${ }^{7}$

Polyarteritis nodosa $(P A N)$. Of 18 patients 5 were 
women, and the mean age was 49 years (range 18-72 years). PAN was diagnosed on the basis of clinical findings and a muscle or kidney biopsy and/or arteriography. Biopsy had to show fibrinoid necrosis of the arterial walls and inflammatory reactions round these. Visceral angiography showed dilatation of arterial segments and areas of irregular narrowing.

Systemic sclerosis (SS). Of the 14 patients all except one were women, and the mean age was 52 years (range 24-76 years). All patients met the criteria given by Masi et al. ${ }^{8}$

Polymyositis and dermatomyositis. The group consisted of 5 women and 3 men; the mean age was 48 years (range 32-64 years). Patients were diagnosed in accordance with the criteria of Bohan and Peter. ${ }^{\circ}$

Wegener's granulomatosis. There were 2 women and 3 men in this group.The diagnosis was based on the clinical findings and on demonstration of a proliferative necrotising arteritis with inflammatory reactions in the surrounding tissue. The mean age was 62 years (range 43-78 years).

$H B s A g$ and anti-HBs were determined by solidphase radioimmunoassays (Ausria and Ausab, Abbott Diagnostic Division, North Chicago, USA).

$\mathrm{HBeAg}$ and anti-HBe were determined by solid-phase radioimmunoassays as previously described. ${ }^{10}{ }^{11}$ Only patients positive for $\mathrm{HBsAg}$ were investigated for $\mathrm{HBeAg}$ and anti-HBe.

\section{Results}

Table 1 shows the distribution of $\mathrm{HBsAg}$ and antiHBs in relation to the diagnostic groups of patients. Only in the patients with SLE was the total prevalence of HBV markers different from the findings in the Danish population ${ }^{12-14}$ when age was taken into account. Among the patients with SLE an increased prevalence of anti-HBs was found in comparison with age-matched control populations. ${ }^{12-14}$ However, except in patients with PAN, no correlation was found when the total prevalence of $\mathrm{HBV}$ markers was related to years elapsed from onset of disease,
Table 2 Distribution of $\mathrm{HBeAg}$ and anti-HBe in HBsAg-positive patients with rheumatic diseases

\begin{tabular}{llll}
\hline $\begin{array}{l}\text { Diagnostic } \\
\text { groups } \\
\text { (number of } \\
\text { patients) }\end{array}$ & $\begin{array}{l}\text { Number } \\
\text { of HBeAg- } \\
\text { positive } \\
\text { patients }\end{array}$ & $\begin{array}{l}\text { Number } \\
\text { of anti- } \\
\text { HBe } \\
\text { positive } \\
\text { patients }\end{array}$ & $\begin{array}{l}\text { Number } \\
\text { with no HBe } \\
\text { markers }\end{array}$ \\
\hline $\begin{array}{c}\text { Rheumatoid } \\
\text { arthritis (3) }\end{array}$ & 1 & 1 & 1 \\
$\begin{array}{c}\text { Polyarteritis } \\
\text { nodosa (3) }\end{array}$ & 3 & 0 & 0 \\
\hline
\end{tabular}

activity of disease, and sex. The finding of $\mathrm{HBsAg}$ in $4 \%$ (95\% confidence limits: $0 \cdot 8-11 \cdot 4 \%)$ of the patients with RA is significantly higher than in the Danish population. HBsAg was found in 3 of 18 patients $(17 \%)$ with PAN ( $99 \%$ confidence limits: $2 \cdot 0-48 \cdot 8 \%$ ), and this prevalence was significantly higher than in the age-matched control populations. Of the 18 patients with PAN 8 were below the age of 50 years and 6 of these were men. The $3 \mathrm{HBsAg}$ - and $\mathrm{HBeAg}$-positive patients were all found among these 6 men. The distribution of $\mathrm{HBeAg}$ and anti-HBe in the HBsAg-positive patients is shown in Table 2. Of the 3 HBsAg-positive women with RA 2 were healthy HBsAg carriers with respect to the liver and both had inactive RA. The third patient, who had both $\mathrm{HBsAg}$ and $\mathrm{HBeAg}$, had progressed from an acute hepatitis to a cirrhosis verified by liver biopsies. This patient had an active RA, and the HBV infection was acquired several years after onset of the RA.

CASE REPORTS OF HBSAg-POSITIVE PATIENTS WITH PAN

Case 1. A 34-year-old man, previously healthy, used opiates during a 3-week holiday in India. During the first 5 weeks after his return he developed loss of appetite, dyspepsia, abdominal pain, pale stools, dark urine, epididymitis, low fever and loss of weight of $10 \mathrm{~kg}$.

On his admission to hospital the following

Table 1 Distribution of $\mathrm{HBs} \mathrm{Ag}$ and anti-HBs in different groups of patients with rheumatic diseases

\begin{tabular}{|c|c|c|c|c|}
\hline Diagnostic groups & $\begin{array}{l}\text { Total number } \\
\text { of patients }\end{array}$ & $\begin{array}{l}\text { Number of } \\
\text { HBsAg-positive } \\
\text { patients (\%) }\end{array}$ & $\begin{array}{l}\text { Number of } \\
\text { anti-HBs positive } \\
\text { patients (\%) }\end{array}$ & $\begin{array}{l}\text { Total } \\
\text { prevalence of } \\
\text { HBV markers } \\
\text { in } \%\end{array}$ \\
\hline $\begin{array}{l}\text { Juvenile rheumatoid arthritis } \\
\text { Rheumatoid arthritis } \\
\text { Polymyalgia rheumatica } \\
\text { Temporal arteritis } \\
\text { Systemic lupus erythematosus } \\
\text { Polyarteritis nodosa } \\
\text { Systemic sclerosis } \\
\text { Polymyositis/dermatomyositis } \\
\text { Wegeners granulomatosis } \\
\text { Total }\end{array}$ & $\begin{array}{r}34 \\
74 \\
27 \\
27 \\
32 \\
18 \\
14 \\
8 \\
5 \\
239\end{array}$ & $\begin{array}{ll}0 & \\
3 & \text { (4) } \\
0 & \\
0 & \\
0 & \\
3 & \\
0 & \\
0 & \\
0 & \\
6 & \end{array}$ & $\begin{aligned} 0 & \\
9 & (12) \\
4 & (15) \\
3 & (11) \\
8 & (25) \\
0 & \\
2 & (14) \\
1 & (13) \\
1 & (20) \\
28 & \end{aligned}$ & $\begin{array}{r}0 \\
16 \\
15 \\
11 \\
25 \\
17 \\
14 \\
13 \\
20\end{array}$ \\
\hline
\end{tabular}


biochemical and serological findings suggested disease of the liver: transaminases increased 15 times, alkaline phosphatases 2.5 times, and bilirubin 1.5 times. The prothrombin-proconvertin time was normal. A liver biopsy showed acute hepatitis with inflammatory infiltrates round the arteries.

Other findings suggesting systemic disease were blood pressure $180 / 120 \mathrm{mmHg}$, cardiomegaly, tachycardia, and diffuse infiltrates in the lungs. The patient also had neuropathy in the lower limbs and proteinuria, and a renal biopsy showed changes compatible with PAN.

Treatment with prednisone $80 \mathrm{mg}$ daily was initiated together with treatment of the hypertension. During the following 6 months all symptoms except the hypertension improved and after 14 months steroid and antihypertensive treatment could be stopped. The patient remained HBsAg-positive during the entire follow-up period. However, after one year of follow-up the patient showed a seroconversion from $\mathrm{HBeAg}$ to anti-HBe at a time when he was still on steroid treatment. Transaminases returned to normal after the seroconversion from $\mathrm{HBeAg}$ to anti-HBe. After 4 years of follow-up the patient is still HBsAg-positive and feeling well without treatment.

Case 2. A 25-year-old male who had been a drug addict using opiates for one year was admitted to hospital with a classical acute hepatitis. HBsAg as well as $\mathrm{HBeAg}$ were positive, and a liver biopsy showed acute hepatitis. The patient slowly improved, but 4 months later he was again admitted to the hospital with fever, epididymitis, and loss of weight. The bilirubin was increased $2 \cdot 5$ times, transaminases 14 times, and alkaline phosphatases 3 times, and $\mathrm{HBsAg}$ and $\mathrm{HBeAg}$ were still positive. Two months later the patient developed over a 3-week period abdominal pain, myalgia, headache, hypertension, neuropathy of the lower limbs, low fever, and proteinuria of $4 \mathrm{~g}$ /day. He was again admitted to hospital, where within 12 hours he became unconscious and had grand-mal seizures. The blood pressure was then $240 / 160 \mathrm{mmHg}$. Both a CT scan and the cerebrospinal fluid were normal. Treatment with high doses of prednisone and antihypertensive drugs was started. Renal and mesenteric arteriography showed dilatation of arterial segments as well as areas of irregular narrowing, and a kidney biopsy showed focal ischaemia.

Cyclophosphamide $100 \mathrm{mg} /$ day was added to the treatment. After 3 months of treatment the blood pressure was reduced to $160 / 100 \mathrm{mmHg}$. Fourteen months after his acute hepatitis B the treatment is unchanged and the patient is still $\mathrm{HBsAg}$ - and $\mathrm{HBeAg}$-positive, with biochemical findings suggesting an active liver disease.
Case 3. A 42-year-old male had previously been in hospital several times owing to depressions and abuse of tranquillisers and alcohol. In the course of one month before the present admission to hospital he developed severe peripheral neuropathy, arthralgia, and fever. On admission there was hypertension with tachycardia and ischaemia of the heart. Biochemical findings suggested a slight liver infection. Tests for both $\mathrm{HBsAg}$ and $\mathrm{HBeAg}$ were positive, and a liver biopsy showed nonspecific reactions. Furthermore the patient had proteinuria ( $3.8 \mathrm{~g} /$ day), and a kidney biopsy showed focal proliferative glomerulonephritis. A muscle biopsy showed both fibrinoid necrosis and inflammatory infiltrates of the arterial walls. Treatment was started with prednisone $80 \mathrm{mg} /$ day, digoxin, and antihypertensive drugs. Despite intensive treatment for 5 months the patient slowly deteriorated and died from massive organ infarctions. Necropsy showed massive infarctions of liver and kidney. The patient stayed HBsAg- and $\mathrm{HBeAg}$-positive during the time of observation and had a 3-week period with both detectable HBsAg and anti-HBs, suggesting circulating immune complexes. However, this finding had no obvious influence on the clinical manifestations of the disease.

\section{Discussion}

Bacon and coworkers ${ }^{3}$ have previously found an increased prevalence of anti-HBs in patients with PMR, and a single case of HBV immune deposits in an arterial wall has been reported. ${ }^{15}$. However, using control populations of voluntary blood donors, ${ }^{14}$ unselected hospitalised patients ${ }^{13}$ and Danish dentists, ${ }^{12}$ we could not find an increased prevalence of anti-HBs in PMR when matching for age. This finding is in agreement with those of others. ${ }^{16}{ }^{17}$ Neither did we confirm an increased prevalence of anti-HBs in patients with TA. For the total prevalence of HBV markers in patients with JRA, RA, PAN, and SS no increased age-specific prevalence rates were found. However, 3 out of 74 patients $(4 \%)$ with RA were HBsAg-positive, which is approximately 20 times more than is found in the Danish population. This is in contrast with the patients with JRA, in whom no HBV markers were found. The increased prevalence of $\mathrm{HBs} \mathrm{Ag}$ among the patients with RA cannot be explained by an increased exposure, as the total prevalence of HBV markers is no different from that in the control populations. Thus these patients might have an altered immune response with increased tendency to be $\mathrm{HBsAg}$ carriers. This increased tendency is well known in patients with an otherwise altered immune response, as is found in patients on haemodialysis and in patients with Down's syndrome. ${ }^{18} 19$ 
Our finding of an increased prevalence of $\mathrm{HBV}$ markers among patients with SLE is consistent with the increased tendency to infections among these patients. However, the possible significance of the $\mathrm{HBV}$ infection in the liver diseases in SLE patients is unclear. Liver disease occurs in patients with SLE, ${ }^{20}$ and prednisone is often given. Prednisone is known to increase significantly the survival of patients with autoimmune liver disease, ${ }^{21}$ and this might explain why hepatic involvement is a rarely recognised complication in SLE.

In agreement with others we found an increased prevalence of $\mathrm{HBsAg}$ in patients with PAN. ${ }^{22}{ }^{23}$ Furthermore these patients were all $\mathrm{HBeAg}$-positive at the onset of their disease, indicating an active viral replication. Two of these patients had an onset of the PAN with a biopsy-verified acute hepatitis, and in one the delay between onset of the hepatitis and onset of PAN might indicate that the PAN was triggered off by the HBV infection.

The different clinical outcome of PAN in HBsAgpositive patients is illustrated by the 3 patients described. The patient whose disease had a benign outcome had a seroconversion from $\mathrm{HBeAg}$ to anti-HBe, and approximately 3 months after this seroconversion the medication could be stopped even though the patient stayed HBsAg-positive. In $\mathrm{HBsAg}$ - and $\mathrm{HBeAg}$-positive patients with chronic liver disease it has been shown that a seroconversion from $\mathrm{HBeAg}$ to anti-HBe is often followed by clinical and biochemical improvement. ${ }^{24-26}$ Trepo and coworkers $^{22}$ found that the disappearance of HBsAg in patients with PAN may coincide with clinical improvement, and immune complexes of $\mathrm{HBsAg} /$ anti-HBs may be involved in the pathogenesis. ${ }^{27}$ However, our findings might indicate that circulating immune complexes of $\mathrm{HBeAg} / \mathrm{anti}-\mathrm{HBe}$ may be involved in the pathogenesis of PAN.

In conclusion, our data do not support the idea that $\mathrm{HBV}$ is an aetiological factor in rheumatic diseases except in some cases of PAN.

This work was supported by the Danish Medical Research Council (j.nr. 512-20553), the Ebba Celinder Foundation, Købmand i Odense Johann, and Hanne Weimann b. Seedorff Foundation, and Leo Pharmaceutical Products Foundation.

\section{References}

${ }^{1}$ Gocke D J. Immune complex phenomena associated with hepatitis. In: Vyas G N, Cohen S N, Schmid R, eds. Viral Hepatitis. Philadelphia: Franklin Institute Press, 1978: 277-83.

2 Morris E L, Stevens M B. Rheumatoid arthritis-a sequel to HBsAg hepatitis. Am J Med 1978; 64: 859-62.

${ }^{3}$ Bacon P A, Doherty S M, Zuckerman A J. Hepatitis-B antibody in polymyalgia rheumatica. Lancet 1975 ; ii: $476-8$.
4 Mihas A A, Kirby J D, Kent S P. Hepatitis B antigen and polymyositis. JAMA 1978; 239: 221-2.

5 Brewer E J, Bass J, Baum J, et al. Current proposed revision of JRA criteria. Arthritis Rheum 1980; 23: 195-9.

${ }^{6}$ Ropes M W, Bennet G A, Cobb S, Jacox R, Jessar P A. 1958 revision of diagnostic criteria for rheumatoid arthritis. Bull Rheum Dis 1958; 9: 175-6.

7 Cohen A S, Reynolds W E, Franklin E C, et al. Preliminary criteria for the classification of systemic lupus erythematosus. Bull Rheum Dis 1971; 21: 643-8.

${ }^{8}$ Masi A T, Rodnan G P, Medsger T A, et al. Preliminary criteria for the classification of systemic sclerosis (scleroderma). Arthritis Rheum 1980; 23: 581-90.

- Bohan A, Peter J B. Polymyositis and dermatomyositis. N Engl J Med 1975; 292: 344-7.

10 Aldershvile J, Frösner G G, Nielsen J O, Hardt F, Deinhardt F, Skinh $ø$ j P.Hepatitis B e antigen and antibody measured by radioimmunoassay in acute $\mathrm{HBs} A g$-positive hepatitis. J Infect Dis 1980; 141: 293-8.

11 Aldershvile J, Caspani B, Frösner G G. Hepatitis B e antibody determination. J Clin Microbiol 1980; 11: 458-61.

12 Aldershvile J, Brock A, Dietrichson O, et al. Hepatitis B virus infections among Danish dentists. J Infect Dis 1978; 137: 63-6.

${ }^{13}$ Skinhøj P. Epidemiology of hepatitis B antigen and antibody in hospital patients in Copenhagen. Scand J Infect Dis 1975; 7: 85-9.

${ }^{14}$ Skinhøj P, Nielsen J O, Dietrichson O. Serological evidence of hepatitis B infection in patients with chronic liver diseases. Scand J Gastroenterol 1977; 12: 615-9.

${ }^{15}$ Plouvier B, Wattre P, Devulder B. HBsAg in superficial artery of patient with polymyalgia rheumatica. Lancet 1978; i: 932-3.

${ }^{16}$ Elling H, Skinhøj P, Elling P. Hepatitis B virus and polymyalgia rheumatica. Ann Rheum Dis 1980; 39: 511-3.

${ }^{17}$ Bridgeford P H, Lowenstein M, Bocanegra T S, Vasey F B, Germain B F, Espinoza L R. Polymyalgia rheumatica and giant cell arteritis. Arthritis Rheum 1980; 23: 516-8.

${ }^{18}$ London W T, DiFiglia M, Sutnik A, Blumberg B S. An epidemic of hepatitis in a chronic-hemodialysis unit. N Engl J Med 1969; 281: 571-8.

19 Hawkes R A, Boughton C R, Schroeter D R, Decker R H, Overby L R. Hepatitis B infection in institutionalised Down's syndrome inmates: a longitudinal study with five hepatitis $B$ virus markers. Clin Exp Immunol 1980; 40: 478-86.

${ }^{20}$ Runyon B A, LaBrecque D R, Anuras S. The spectrum of liver disease in systemic lupus erythematosus. Am J Med 1980; 69: 187-94.

${ }^{21}$ Kirk A P, Jain S, Pocock S, Thomas H C, Sherlock S. Late results of the Royal Free Hospital prospective controlled trial of prednisolone therapy in $\mathrm{HBsAg}$ negative chronic active hepatitis. Gut 1980; 21: 78-83.

${ }^{22}$ Trepo C G, Zuckerman A J, Bird R C, Prince A M. The role of circulating hepatitis $B$ antigen/antibody immune complexes in the pathogenesis of vascular and hepatic manifestations in polyarteritis nodosa. J Clin Pathol 1974; 27: 863-8.

${ }^{23}$ Gocke D J, Hsu K, Morgan C, Bombardieri S, Lockshin M, Christian C L. Association between polyarteritis and Australia antigen. Lancet 1970; ii: 1149-53.

${ }^{24}$ Aldershvile J, Nielsen J O, Dietrichson O, Hardt F, Juhl E, Tage-Jensen $U$. Long-term follow-up of e-antigen (HBeAg)-positive acute viral hepatitis. Scand J Gastroenterol 1979; 14: 845-8.

25 Aldershvile J, Roggendorf M, Kryger P, et al. Anti-HBc of IgM class, $\mathrm{HBeAg}$ and anti-HBe in patients with acute and chronic hepatitis B. Liver in press.

${ }^{26}$ Realdi G, Alberti A, Rugge M, et al. Seroconversion from hepatitis B e antigen to anti-HBe in chronic hepatitis B virus infection. Gastroenterology 1980; 79: 195-9.

${ }^{27}$ Drüeke T, Barbanel C, Jungers P, et al. Hepatitis B antigenassociated periarteritis nodosa in patients undergoing long-term hemodialysis. Am J Med 1980; 68: 86-90. 